\title{
NAGY LÁSZLÓ \\ Alekszej Csheidze, egy Magyarországon harcolt szovjet katona feljegyzései
}

\section{Csheidze müvének történelmi kontextusa és általános jellemzői}

A legnagyobb jóindulattal sem állíthatjuk, hogy Magyarországon manapság divat lenne az egykor hazánk területén harcolt szovjet katonák visszaemlékezéseinek kiadása. Ez egyfelől érthetö, hiszen a közös múlt szóban forgó fejezete finoman fogalmazva is terhelt, másfelől azonban mégiscsak a magyar történelemnek olyan fejezetéről van szó, amelynek jelentőségét aligha lehetne túlbecsülni. Még egyszerübben fogalmazva: tetszik, nem tetszik, a témával mindenképp foglalkoznunk kell. A kérdés örök aktualitását mutatja többek közt az a rendkívül heves történészvita is, amely 2016. február 18-án Krausz Tamás és Ungváry Krisztián között a Kossuth Klubban zajlott, és amelynek fő témája épp Magyarország második világháborús részvétele volt. ${ }^{1}$

A magyarországi hadszíntéren a harcok 1944. augusztus 25-től 1945. április 12-ig, vagyis közel nyolc hónapon át tartottak. A Vörös Hadsereg kötelékéből több millió szovjet katona vett részt a hazánk területén zajlott hadmüveletekben, és a Titkositás feloldva: A Szovjet Fegyveres Erök háborús veszteségei a harci cselekmények és a katonai konfliktusok során címü munka ${ }^{2}$ adatai szerint közülük mintegy száznegyven ezren estek el a harcok során. A konkrét harci cselekményekben való részvétel mellett a szovjet katonák ténykedése a népirtástól az embermentésig ${ }^{3}$ terjedően rendkívül

\footnotetext{
${ }^{1}$ A vitaestről számos korabeli újságcikk is beszámolt, maga a beszélgetés pedig megtekinthető a különböző internetes videómegosztó csatornákon. Például: Krausz-Ungváry vita a Kossuth Klubban. https://www.youtube.com/watch?v=YJjPUB7O-04 (Letöltés ideje: 2020. február 18.)

${ }^{2}$ Grif szekretnosztyi sznyat: Potyeri Vooruzsennih szil SZSZSZR v vojnah, bojevih gyejsztvijah $i$ vojennih konfliktah. Sztatyisztyicseszkoje isszledovanyije, szerk. G. F. KRIvosejevA, Moszkva, Vojenizdat, 1993, 325. - A katonasírokban nyugvó elhunytak száma ennél némileg kevesebb, 112.625 fö. Lásd Ih podvig besszmertyen 1941-1945, szerk. A. Voloszkov et al., Moszkva, Leszar-Art - Prava cseloveka, 2008, 45. Az akkori - a mainál majdnem kétszer nagyobb területü! - ország területén harcoló szovjet katonák összlétszámáról sajnos nincsen hivatalosan hozzáférhető adat. A számítást egységekre lebontva kellene elvégezni ahhoz, hogy legalább nagyságrendileg pontos létszámot kapjunk. Egyetlen beszédes adat: Számvéber Norbert számításai szerint (Az alföldi páncéloscsata: Harcok a Tiszántúlon, 1944. október, Debrecen, Puedlo Kiadó, 2007, 171.) egyedül a II. Ukrán Front nagy alföldi páncéloscsatájának szovjet embervesztesége 84.010 fő volt (ebből 19.713 halott, 64.927 sebesült), a hadseregcsoport összlétszáma pedig az offenzíva kezdetén 698.200 föt tett ki.

${ }^{3}$ A 1945. március 16-i hírhedt Gánt-kápolnapusztai vérengzésről lásd Kováts László, Egy csepp a tengerben, cseppben a tenger, Bolyai Szemle, 2000/1, 137-158. - Az eseményt érdemes összevetni a jóval kevéssé ismert temerini, pontosabban újvidéki esettel: Dujmovics György, Hogyan mentették meg az oroszok az Ujvidékre hajtott temerinieket? = A temerini razzia, szerk. ÁdÁm István et al., Temerin, A VMDP Történelmi Bizottsága, 2001, 170-172.
} 
sokrétű volt, amelyet e rövid írás még csak vázlatosan sem kísérel meg bemutatni, ehelyett inkább egy egészen más módszerhez folyamodik: egy Magyarországon harcolt szovjet katona, nevezetesen a grúz Alekszej Alekszandrovics Csheidze feljegyzéseit fogja elemezni, mégpedig elsősorban fordítástechnikai szempontból.

A rendelkezésre álló orosz nyelvű katonai irodalmat meglehetősen jól leszűkíti Andrej Vjacseszlavovics Vaszilcsenko 100 nap a véres pokolban, Budapest: „A dunai Sztálingrád?" címü művének ${ }^{4}$ irodalomjegyzéke, amely egy tucatnál is több értékes forrásmüvet sorol fel. A 21. századi kutató dolgát jelentősen megkönnyíti továbbá az a körülmény, hogy a szovjet katonák visszaemlékezéseit tartalmazó művek döntő többsége az Interneten is hozzáférhetö, elsősorban a Военная литература (Katonai irodalom) címü gyüjtőportálon. ${ }^{5}$ Vaszilcsenko történész könyve ugyan kifejezetten a Budapestért vívott csatáról szól, ám a hivatkozott források túlnyomó része egy-egy katona teljes háborús életútját végigkíséri, vagyis röviden: olyan háborús naplókról, illetve visszaemlékezésekről van szó, amelyekben legfeljebb egy-két fejezet foglalkozik a magyarországi eseményekkel. A választásom azért esett épp Alekszej Csheidzére, mert ő a szó valódi értelmében vett „elitkatona” volt, aki a magyarországi harcokban a Dunai Flottilla (Дунайская флотилия) felderítőjeként vett részt. ${ }^{6}$ Könyve elöször 1982-ben jelent meg Egy dunai felderitó feljegyzései ${ }^{7}$ címmel, amelyet azután két újabb kiadás követett, 1984ben, illetve 1989-ben.

Maga a mü sok tekintetben egy tipikus szovjet háborús napló stílusjegyeit viseli magán, ami egyébként az átlagos mai olvasó számára akár még érdekes is lehet, sőt az újszerüség erejével is hathat, tekintettel arra, hogy Magyarországon immár több mint harminc éve lényegében nem adnak ki szovjet háborús irodalmat. Viszonylagos

\footnotetext{
${ }^{4}$ A. V. Vaszilcsenko, 100 dnyej v krovavom adu. Budapest: „dunaszkij Sztálingrád”? Moszkva, Jauzapressz, 2008.

${ }^{5}$ http://militera.lib.ru/ (Letöltés ideje: 2020. február 18.)

${ }^{6}$ A rendkívül tragikus sorsú Alekszej Alekszandrovics Csheidze (Алексей Александрович Чхеидзе) 1927-ben született Tifliszben, a mai Tbilisziben. 1943 szeptemberében, vagyis mindössze tizenhat éves korában komszomolistaként csatlakozott a Fekete-tengeri flottához, majd a kiképzés befejeztével a Dunai Flottillához irányították, amelynek kötelékében - felderítőként - végigharcolta a háborút Odesszától egészen Bécsig. Harctéri érdemei elismeréseként hatszor részesült katonai kitüntetésben: kitüntetettje többek közt a „Budapest Bevételéért” emlékéremnek is. Bécs elfoglalását/felszabadítását követően viszszahelyezték Budapestre, mivel a Flottillának révkalauzokra volt szüksége a dunai hajóközlekedés zavartalanságának biztosításához. 1945 júniusában - tehát már az európai háború befejezése után! - hajója aknára futott és felrobbant. A robbanást ugyan túlélte, de olyan súlyos sérüléseket szenvedett, hogy 1948-tól egészen 1992-ben bekövetkezett haláláig - vagyis több mint 40 éven keresztül - a Szerpuhov melletti Danki hadirokkantakat befogadó fekvőbeteg-ellátó intézetének gondozottja maradt. Akaratereje, belső tartása azonban nem hagyta el, és tulajdonképpen ennek köszönhető az, hogy minden kommunikációs nehézség ellenére sikerült kiadnia háborús visszaemlékezéseit. Említésre érdemes továbbá, hogy Gennagyij Dobrov grafikusművész A háború autogramjai (Автографы войны) című, rendkívül megrázó képsorozatában a háborús sérüléseket szenvedett Csheidzéről is készített portrét.

${ }^{7}$ Alekszej Alekszandrovics Csheıdze, Zapiszki dunajszkovo razvedcsika, Moszkva, Molodaja gvargyija, 1982.
} 
időszerűtlenségük ellenére azonban e háborús feljegyzések kifejezetten érdekesek; müfaji sajátosságukból adódóan az eseményeket sokkal színesebben taglalják, mint a szaktörténészi munkák, ugyanakkor nem szakadnak el úgy a valóságtól, mint a háborús regények többsége. Sőt, egyáltalán nem szakadnak el a valóságtól, csupán - megint csak müfaji sajátosságukból adódóan - nem képesek arra, hogy mindent átfogó összképet nyújtsanak a háborúról, vagyis szükségképpen töredékesek és megmaradnak a szubjektív „én így láttam” szintnél.

A harc eseményeinek és néhány személyes epizódnak tárgyilagos bemutatásán túl Csheidze visszaemlékezései révén csak nagyon keveset tudunk meg az élet egyéb dolgairól, viszont mivel ez a kevés információ első kézből származik, ezért alapvetően mégis egy nagyon értékes és izgalmas forrásmüről beszélhetünk. A hivatalos kommunista ideológia - nyíltan legalábbis - gyakorlatilag egyáltalán nincs jelen a müben, viszont minden ellenség a „fasiszta” gyüjtônév alatt szerepel, ami egyértelműen a kor szándékosan leegyszerüsítő szemléletmódjának tudható be. A magyarok kifejezetten pozitív színben tünnek fel, akik Európa más népeihez hasonlóan elszenvedték a német megszállást, és akik a szovjet katonákat mint felszabadítókat üdvözölték. Az unásig ismételt „Hitler utolsó csatlósai” szemléletnek a nyomát sem találni, a könyvben szereplő magyarok - katonák és civilek egyaránt - mindannyian a Szovjetunió győzelméért küzdöttek; a sérült szovjet katonákat a hadikórházból kimenekítő Szabó házaspártól kezdve a Budai Önkéntes Ezred katonáin át egészen egy Kocsis Mari nevü diáklányig, aki kitűnő helyismeretének köszönhetően több értékes felderítő akció során is segítette a szovjeteket. Az egész művet egyfajta „дружба народов” (népek barátsága) stílus hatja át, ami még akkor is figyelemreméltó - és elismerendő -, ha nem lehet nem észrevenni, hogy itt jórészt a háború tudatos idealizálásának lehetünk tanúi, egy-két utólagos betoldás pedig nagy valószínűség szerint a gondos lektori munka eredménye. ${ }^{8}$ Vegyük például az alábbi, kissé ideológiai színezetű mondatot: „A pincékből elöjöttek a túlélők. Sírtak az örömtől [плакали от счастья], és köszönetet mondtak nekünk, szovjet katonáknak, hogy elhoztuk a felszabadulást a magyar föváros számára."9 A Budapest

\footnotetext{
${ }^{8}$ Azzal kapcsolatban, hogy ez a stílus mennyire nem volt általános akkoriban, csupán egyetlen apró adalék: az OGIZ GISZ (az Âllami Könyvkiadó Vállalat) által a második világháború sűrűjében, 1943-ban kiadott első magyar-orosz katonai szótár bevezetője a magyar katonákat nemes egyszerüséggel „elállatiasodott fasiszta bandáknak" (озверелые фашистские банды) nevezi. Azon túlmenően, hogy egymás minősítgetése nyilvánvalóan oda-vissza irányba működött, e kifejezés sajnos sokkal életszagúbb, mint néhány, a múltat megszépíteni akaró háborús visszaemlékezés „egydimenziós” szemlélete.

${ }^{9}$ Lényegesen reálisabb képet ad a háború mindennapjairól például a 3. Ukrán Front Katonai Tanácsának 084. sz., 1944. december 19-i határozata: „A személyi állományhoz tartozók elkövettek 110 rendbontást, erőszakot, valamint gyilkosságot és testi sértést. [...] Ezek a tényállások nem csökkennek, hanem ugrásszerüen sokasodnak. [...] A részegeskedés és a katonai fegyelem megsértése, az egyes személyek »nekünk mindent szabad « hanyagsága, továbbá az e jelenségekkel szembeni határozott fellépés gyengülése aláássa a katonai fegyelem - mint a rend és a harckészség - alapjait." Forrás: UngvárY Krisztián, MeruK József, Budapest a szovjet vezetési szintü hadmüveleti iratokban (1944-1945).
}

http://bfl.archivportal.hu/sites/default/files/atoms/files/ukmjbfl_szovjetforrasok.pdf (Letöltés ideje: 2020. február 18.) 
körüli harcok leírása során Csheidze következetesen az освобождение (felszabadítás), nem pedig a később hivatalossá vált взятие (bevétel, elfoglalás) kifejezést használta, amely az 1945. június 9-én alapított katonai emlékérmen is szerepel: медаль „За взятие Будапешта” (Budapest Bevételéért emlékérem).

E háborús napló további előnye, hogy egyáltalán nem szakszövegről van szó, holott Csheidze szemmel láthatóan komoly katonai, illetve müszaki szakértelemmel rendelkezett. A szakmai ismeretek hiányát a minimális tájékozottság és a téma iránti érdeklődés tehát messzemenően kompenzálni tudja. Egy másik igen jellemző stílusjegy, hogy a mondatok helyenként túl rövidek, és nem ritka a szóismétlés sem. A „был” (volt) szó használata feltűnően gyakori, néha egy mondaton belül többször is előfordul, például itt: „Высокая худощавая Юца была не очень заметной девушкой, но она была очень доброй и заботливой, хорошо готовила обеды и следила, чтобы все наши разведчики всегда были вовремя накормлены." ${ }^{\prime 0}$ Mindez azonban nem feltétlenül értékelendő negatívan: egyrészt bizonyítja, hogy a szerző nem szépíró, hanem valódi katona volt, másrészt épp az ilyen apró részletek alapján gyanítható, hogy utólag nem „nyúltak bele” szándékosan a szövegbe, és a szöveggondozás csak egészen minimális mértékü volt.

Azon se lepődjön meg senki, hogy Csheidze rengeteg nevet említ meg a beszámolójában, akiknek túlnyomó többsége az olvasó számára - ma már - szinte semmit nem mond, a harcostársak részletekbe menő felsorolása legföljebb a hadtörténészek és a hozzátartozók számára szolgál érdekes adalékként. Mindezen apró „szépséghibák" ellenére - amelyeket hiányosságnak még a legnagyobb rosszindulattal sem lehetne nevezni - egy ilyen háborús napló kiválóan alkalmas néhány közkeletűvé vált sztereotípia eloszlatására. Lássunk néhányat ezek közül:

1) Sokak „megalapozott” állításával ellentétben a szovjet hadsereg nem „az oroszok". Ennek alátámasztására szükségtelen bármiféle magyarázatot füzni azon kívül, hogy megemlítjük: maga Csheidze is grúz volt.

2) A szovjetek nem is tudtak igazán harcolni, és győzni is csak azért voltak képesek, mert létszámfölényben voltak. Csheidzének és társainak tettei egyértelműen - ráadásul a lehető legemberibb nézőpontból bemutatva - igazolják, hogy itt korántsem csak erről volt szó. Az egyik legemlékezetesebb vállalkozásuk során például több kilométert tettek meg a budai vár környékének szennyvízcsatorna-hálózatában, hogy az ellenség háta mögé kerülve értékes információkat, illetve foglyokat szerezzenek. Amikor a front túloldalán kimásztak a csatornából, megdöbbenve állapították meg, hogy a németek még a legalapvetőbb óvintézkedések megtételét is elmulasztották, avagy hősünk szavaival élve „a fasiszták meg voltak győződve arról, hogy a hátországukba nem juthatnak el a szovjet felderítők". Egy másik alkalommal a lerombolt esztergomi híd víz alatt lévő roncsainak felkutatásával kellett biztosítaniuk a szovjet

${ }^{10}$ „A magas, vézna Juca nem volt éppen feltűnő jelenség, viszont nagyon jószívű és gondoskodó volt, finom ebédeket fözött, és ügyelt arra, hogy minden felderítőnk mindig időben el legyen látva." 
hajók továbbjutását. A felderítés során helyenként derékig gázoltak a jeges vízben, mire elértek egy megfigyelóállást. Nyilvánvaló, hogy az ilyen és ehhez hasonló haditetteket nem lehet valódi lelkesedés nélkül végrehajtani.

3) Bár egy frontnaplóból erre következtethetünk a legkevésbé, az is nyilvánvaló túlzás, hogy minden szovjet katona kegyetlen lett volna. Az értő olvasó számára talán már az a néhány apró életkép is, amely e feljegyzés lapjain felvillan elöttünk, alkalmas arra, hogy megmutassa a szovjet fél hétköznapi, szorosabban vett emberi oldalát is, és véget vessen ennek a sztereotípiának.

\section{Fordítási nehézségek}

A mű általános jellemzőinek áttekintését követően vizsgáljunk meg néhány fordítási nehézséget, illetve egyéb érdekességet a konkrét szöveg kapcsán. Kezdjük a korabeli szovjet és magyar reáliákkal. A fordítási példák ismertetésénél néhány esetben a Dunántúli Napló 1977. évi 2. számában megjelent Földalatti felderítés című cikkre, ${ }^{11}$ illetve a 2019 ősz óta az Interneten is olvasható Sárosi Ádám-féle Csheidze-fordításra (Egy dunai felderítő feljegyzései) ${ }^{12}$ is hivatkozni fogok. Külön érdekesség, hogy e munkákról csak utólag értesültem, így azokat a saját fordításom elkészítése során (2018 ősze) nem állt módomban figyelembe venni.

A háború elött motorsporttal is foglalkozó Csheidze harci érdemei elismeréseképpen egy zsákmányolt DKW típusú német motorkerékpárt kapott ajándékba a parancsnokságból. A hivatalos dokumentumon ez állt: „Выдано водителю тов. Чхеидзе Алексею А. войсковой части пп 90757 в том, что за ним закреплен мотоцикл № 34 (№ Ф-74-03-52)”, ami magyarul a következőket jelenti: „Kiállítva Alekszej A. Csheidze et., 90757 irányítószámú katonai alakulat járművezetője részére. Egyúttal a 34. sz. motorkerékpárt (forgalmi rendszám: F-74-03-52) rendelem ki a számára”. A „пп” „полевая почта”-t, vagyis tábori postát jelent (amely egyébként szinte szó szerinti megfelelöje a német „Feldpost”-nak), tehát a „90757” minden valószínűség szerint irányítószámot jelöl. A „за ним закреплен” (rendelem ki a számára) kifejezés pedig arra utal, hogy a szóban forgó motorkerékpárt Csheidze kizárólag használatba kapta, vagyis az továbbra is a szovjet hadsereg tulajdonát képezte.

\footnotetext{
${ }^{11}$ A. A. Csheidze, Földalatti felderités, Dunántúli Napló, 1977/2, 101. (Az eredeti forrás és a fordító megjelölése nélkül.) Az értékes dokumentumok összegyüjtése és közlése Andrej Ogoljuk fáradhatatlan munkáját dicséri. - Miután ez az írás - tartalmilag is - jelentős mértékben eltér a saját fordításomtól, ezért vagy nem volt szöveghű a fordítás, vagy több eredeti változat is közkézen forgott. Az utóbbi lehetőség mellett szól, hogy Csheidze visszaemlékezései könyv formájában először csak öt évvel később, 1982-ben jelentek meg.

${ }^{12}$ https://pomz.blog.hu/2019/09/27/egy_dunai_felderito_feljegyzesei (Letöltés ideje: 2020. február 18.) Sárosi Ádám Csheidze magyarországi feljegyzéseit 2019. szeptember 27. és 2020. január 20. között öszszesen öt részben tette közzé.
} 
A már említett földalatti felderítést nem lehetett volna végrehajtani, ha a szovjet katonákat nem segítette volna „egy csatornarendszer-üzemeltetéssel foglalkozó nyugdíjas mérnök, aki korábban a budapesti városháza tisztviselőjeként dolgozott.” Az orosz eredetiben a titulus így hangzik: „пенсионер, бывший служащий Будапештского муниципалитета”. А „муниципалитет” magyarítása során az alábbi lehetőségeket vettem számításba: a „polgármesteri hivatal” vagy az „önkormányzat" túlságosan mai, vagyis 1990 utáni elnevezések, ezért a múltba történő viszszavetítésük nem túl szerencsés megoldás; nem sokkal jobb a „törvényhatósági bizottság" megnevezés sem, amely ugyan korabeli kifejezés, de túl hivatalos, ráadásul hosszú is, így legcélszerübbnek a neutrális ,városháza” fordítás mutatkozott. ${ }^{13}$ Hasonló, de egyszerübb példa a Testnevelési Főiskoláé, amely az eredeti orosz szövegben így szerepelt: „Особенно мы подружились с сержантом Яношем Секерешем и рядовым Дюркой То-том. Оба они были студентами Будапештского института физкультуры." ${ }^{14}$ Itt az egyetlen problémát az jelenthette, hogy az 1925-ben megnyitott intézmény akkor még nem volt egyetem - mint ma -, hanem a Magyar Királyi Testnevelési Főiskola nevet viselte. Mintegy közbevetésként jegyzem meg, hogy ahol lehet, érdemes lábjegyzetben jelezni a magyar reáliákkal kapcsolatban felmerülö kisebb pontatlanságokat: „Másnap Budán, a Gellért-hegyen (ma Szabadság-hegy) az egész Budai Ezred összegyült." Nem a Gellért-hegyet, hanem a Széchenyi-hegyet hívták 1945-1990 között Szabadság-hegynek.

Nézzünk két nagyon rövid példát többszöri át-, illetve visszafordításokra: A „бригады штурмовых орудий” magyar megfelelőjét (rohamlöveg-dandár) akkor kapjuk meg helyesen, ha előbb utánanézünk az alapul szolgáló eredeti - vagyis német - kifejezésnek (Sturmgeschütz-Brigade), és nem közvetlen fordítással próbálkozunk. A fentihez valamelyest hasonló a szerb „Любиша Жоржевич” esete, akit a magyar szövegben akár szerbesen Ljubiša Đorđević (saját megoldásom), akár magyarosan Gyorgyevity (esetleg Gyorgyevics) név alatt is szerepeltethetünk, amennyiben azonban ez utóbbi lehetőség mellett döntünk, akkor célszerűbb az eredeti szerb, nem pedig az orosz („Zsorzsevics”, lásd a Dunántúli Naplóban megjelent változatot) kiejtéshez igazodni.

A teljesség kedvéért hozzá kell tenni: a visszafordítások terén a fordítónak koránt sincs mindig ekkora szerencséje. Míg például a Ferenc József híd (мост ФранцаИосифа) esetében vagy eleve tudott, vagy nagyon könnyen kinyomozható, hogy a mai Szabadság hídról van szó, addig a Mária Lujza utca esetében még egy alapos fordítótól sem várható el, hogy kiderítse: melyik mai utcát rejti magában ez a név - feltéve persze, hogy nincs szó elírásról. E munka természetesen csak akkor spórolható meg, ha - mint a jelen esetben - a szóban forgó utcanév marginális jelentőségű a szövegben.

\footnotetext{
${ }^{13}$ A teljesség kedvéért: a Dunántúli Napló „városi Köztisztasági Hivatalt”, Sárosi pedig „budapesti önkormányzatot" említ.

${ }^{14}$ „Szekeres János őrmesterrel és Tóth Gyurka közlegénnyel különösen jól összebarátkoztam. Mindketten a Budapesti Testnevelési Föiskola hallgatói voltak."
} 
Látszólag jelentéktelen apróság, de számolnunk kell vele, hogy egy magyar neveket tartalmazó lista („Батори Бела, Ахел Дюла, Ласло Ференс, Варга Габор, Бурка Эндрэ”) esetén korántsem egyértelmü az egyes nevek magyar helyesírása. A jelen esetben további kutatást igényelt volna, hogy a Budai Önkéntes Ezred öt katonájából kettőnek a nevét valóban Báthori (és nem mondjuk Báthory vagy Bátori) Bélaként, illetve Áchel Gyulaként kell-e átírni, s nem másképp. Sőt, ad absurdum olyan is elöfordulhat, hogy nincs semmiféle összehasonlítási alapunk, mivel a fenti személyek közül egyesekről csak és kizárólag Csheidze tesz említést.

Még bosszantóbb a dolog akkor, ha nem felsorolásról, hanem olyan személyekről van szó, akiknek valamilyen konkrét szerepük van a szövegben, bármilyen csekély legyen is az. A „rejtélyes” Gyereszkál Sándorné és Mászonyi László esetében pontosan ez a helyzet. Az oroszul „Дерескаль”-nak, illetve „Масоний”-nak írt nevek többé-kevésbé betű szerinti átírása tulajdonképpen kényszermegoldás, hiszen majdnem biztos, hogy ilyen vezetéknevek nincsenek a magyarban. (És még a szabadkőművesség sem jöhet számításba, hiszen az oroszul „масонский”.)

Vegyünk ezek után két földrajzi érdekességet. Miután befejeződtek a Budapestért vívott harcok - írja Csheidze -, „a felderítőket több csoportra osztották. A mi négyesünknek (Globának, Đorđevićnek, Gurának és nekem) az volt a feladata, hogy vizsgáljuk meg azt a lánchidat, amelyen keresztül északról lehet eljutni a Margit-szigetre." A mondat utolsó része oroszul így hangzik: „обследовать цепной мост, который подходил с севера к острову Маргит". Már a budapesti hidak elhelyezkedésének minimális ismerete alapján is látszik, hogy itt nagy valószínűséggel nem a Széchenyi lánchíd önkényes „áthelyezéséről” van szó, hanem az Árpád híd elődjéről, amelynek építését már 1939-ben megkezdték, de a háború miatt öt évig (1943-48) szüneteltek a munkálatok, s a hidat végül csak 1950-ben adták át. A „lánchíd” megnevezés tehát nem elírás, hanem minden bizonnyal erre a hídkezdeményre utal.

Sokkal problémásabb viszont az „esztergomi vasúti híd”, illetve az „esztergomi hidak" kifejezések értelmezése, mivel Esztergomnál mindig is csak egy híd volt, amely kizárólag közúti forgalmat bonyolított. (Mind az esztergomi, mind a túloldalon lévő párkány-nánai vasútállomás több kilométerre van a Dunától, s közöttük soha nem is volt vasúti összeköttetés.) „Március 15-én azt a parancsot kaptuk, hogy keljünk át a Duna jobb partjára Esztergomnál, és a lerombolt esztergomi híd környékén vizsgáljuk át a folyópartot." Eddig még minden világos, a beszámoló azonban a következőképpen folytatódik: „Feltűnt előttünk egy sötét folt. Egy nagy vasúti híd romjai voltak, amelyet a fasiszták azért robbantottak fel, hogy elzárják az utat a szovjet hajók elöl.” („Впереди показалось темное пятно. Это были развалины большого железнодорожного моста, который фашисты взорвали, чтобы преградить путь советским кораблям.”) Márpedig a legközelebbi vasúti híd Komáromnál, vagyis jó ötven kilométerrel nyugatra található. Ekkora tévedésről egy profi katona esetében aligha lehet szó, föleg, hogy a tágabb szövegkörnyezetet tekintve épp az ún. táti hídföért vívott csata tárgyalásánál vagyunk, amely hídfö nemcsak hogy jóval közelebb van 
Esztergomhoz, hanem Komáromig a Vörös Hadsereg ekkor még - nyilvánvalóan - el sem jutott.

Nem sokkal ezután pedig arról olvashatunk, hogy „a hajók haladását megnehezítették a felrobbantott esztergomi hidak.” („Проходу кораблей мешали взорванные эстергомские мосты.”) Egy másik szovjet szerző, Mihail Vlagyimirovics Asik hadnagy, a 83. tengerészgyalogos dandár 144. tengerészgyalogos zászlóalja egyik lövészszakaszának parancsnoka visszaemlékezéseiben egyébként szintén említést tesz a „felrobbantott esztergomi vasúti hídról”. ${ }^{15}$ (És a félreértések elkerülése végett még egy utolsó megjegyzés: az Újpesti vasúti hidat [Északi összekötő vasúti híd] a „népnyelv” néha szintén esztergomi vasúti hídnak nevezi, mivel az a Budapest-esztergomi vasútvonalon található, a konkrét szövegben azonban ez a verzió nem jöhet számításba.)

Ehhez hasonló kisebb-nagyobb anomáliákkal sajnos akkor is számolni kell, ha a szöveg olvasása során nyilvánvalónak tünik, hogy a kiadás elötti változatot átnézte egy magyar lektor, vagy legalább egy olyan korrektor, aki a magyar tulajdonnevek helyesírásával többé-kevésbé tisztában volt, és azokat felismerhető módon ültette át oroszra.

\section{A katonai nyelv kifejezéseinek fordítása}

Külön elemzést igényel a katonai nyelv speciális kifejezéseinek magyarítása, amelyek közül azonban most - mintegy szúrópróbaszerűen - csak a rendfokozatok („rangok") kérdéskörével foglalkozunk részletesebben. A fordítás ugyanis itt egyáltalán nem magától értetődő, ahogy esetleg első ránézésre gondolhatnánk. Induljunk ki mindjárt Csheidze rendfokozatából. Az orosz „старший краснофлотец” „képesített vörösmatróz”-ként fordítása meglehetősen hosszú „értékelő-elemző munka” eredménye, ahol az első nehézséget rögtön az adta, hogy nincs közvetlen összehasonlítási lehetőségünk. Magyar tenger, illetve haditengerészet híján visszamehetünk ugyan a boldog békeidőkbe, de a már több mint száz éve megszűnt császári és királyi haditengerészetnél is csak német rendfokozatokat fogunk találni. Két lehetőségünk marad tehát: külföldi példákhoz, vagyis külföldi haditengerészetek rendfokozatainak többé-kevésbé (de inkább kevésbé) meggyökeresedett magyar fordításaihoz, vagy a jelenlegi magyar civil (folyami) hajózásnál alkalmazott megkülönböztető jelzésekhez - esetleg a két módszer sajátos keverékéhez - folyamodunk. A lényeg, hogy legyünk következetesek, alkossunk rendszert. Természetesen sokkal könnyebb helyzetben vagyunk akkor, ha viszonylag rövid a szövegünk, vagy ha egy hosszabb szövegben kevés, egymástól különböző rendfokozat fordul elő. Ekkor ugyanis elég, ha találunk (pontosabban: alkotunk) egy szépen hangzó magyar kifejezést, és a probléma máris

${ }_{15}$ M. V. Asıк, 83-ja otgyelnaja Novorosszijszko-Dunajszkaja dvazsdi Krasznoznamjonnaja orgyena Szuvorova Brigada Morszkoj pehoti, 1941-1945, Moszkva, AszKON, 2008, 234. (Sárosi Ádám szíves közlése.) 
megoldottnak látszik. Sokkal nagyobb azonban a kihívás, ha szövegünkben a szovjet haditengerészet teljes rendfokozati repertoárja felvonul elöttünk. Csheidze visszaemlékezései esetében azonban nem ez volt a helyzet, mivel mindössze két „nem hagyományos" rendfokozat magyarítását kellett megoldani. (Hagyományosnak tekinthetjük például a tengernagy, ellentengernagy elnevezéseket.)

A „старший краснофлотец”-ről annyit még egy fordítónak is illik tudnia, hogy az a „sima” краснофлотец-cel együtt a legénységi („рядовой”, magyarul kb. tisztes) állománycsoport magasabb rendfokozatát jelöli, amit valamilyen módon a fordításban is érzékeltetni kell. A szóba jöhető variánsok nagyjából a következők: fömatróz (hagyományos, szárazföldi rendfokozatokhoz illeszkedő fordítás), törzsmatróz (a szárazföldi törzsőrmester, illetve törzszászlós mintájára), képesített, illetve szakképzett matróz, mely utóbbi két megkülönböztető jelzőt a civil hajózás használja. A végső döntést semmi más nem motiválta, mint a minél magyarosabb hangzás, így lett a rendfokozat magyar elnevezése: képesített vörösmatróz.

A másik esetben is hasonló szempontok játszottak közre, és a „главный старшина"-ból végül tengerészzászlós lett. ${ }^{16} \mathrm{Ez}$ egyúttal a régi osztrák-magyar haditengerészet „Seefähnrich” rendfokozatának magyar megnevezése is. Itt azonban amennyiben szélesíteni kívánjuk a kört - már szembeütközünk a korábban jelzett problémával; vagyis míg az osztrák-magyar haditengerészet „Fähnrich” (zászlós) állománycsoportjához kettő, addig a neki (nagyon leegyszerüsítve) megfelelő szovjet „младший начальствующий” (kb. fiatal elöljáró) állománycsoporthoz már négy rendfokozat tartozik, tehát a közvetlen fordítás módszere csődöt mond.

Érdekes, hogy az egyébként rendkívül részletes, több mint 1100 oldalas orosz-magyar katonai szótár ${ }^{17}$ a szovjet rendfokozatok ismertetését egyáltalán nem viszi túlzásba. Míg például az NDK Nemzeti Néphadseregének rendfokozatai külön táblázatban szerepelnek, addig a „старший краснофлотец” teljesen kimaradt belőle, a „главный старшина” pedig egyszerűen „fötörzsőrmesterként” szerepel, holott ez utóbbi kizárólag a szárazföldi erőknél rendszeresített rendfokozat. A szótár függeléke következetesebb: a "Szovjet fegyveres erők" címet viselő táblázatában ${ }^{18}$ már megjelenik a „главный старшина”, mégpedig „fötiszthelyettes” néven. A korábban rendszeresített, vagyis a szótár kiadásának idején már „nem hatályos” (megszünt) rendfokozatokról viszont nincs semmiféle összesítő, egységesítő vagy bármilyen egyéb táblázat, holott ennek épp a háborús dokumentumok (tehát nemcsak irodalom) fordítása szempontjából igenis lenne jelentősége. Az orosz „старший морской начальник” elnevezésű beosztás (tehát nem rendfokozat!) „vezető tengerésztiszt”-ként fordítása

\footnotetext{
${ }^{16}$ Sárosinál ezek a rendfokozatok: „rangidős vörösflottilás”, illetve „őrmester”.

${ }^{17}$ Orosz-magyar katonai szótár, szerk. Tóтн Lajos, Bp., Honvédelmi Minisztérium - Akadémiai, 1976.

${ }^{18}$ Uo., 1144-1145. - A teljesség kedvéért tegyük hozzá, hogy e függelék használja a „tengerészzászlós” kifejezést is, amely a szovjet „мичман” magyar megfelelöje. А „старший краснофлотец” viszont kimaradt a táblázatból, mivel ezt a rendfokozatot 1946-ban megszüntették, és azt felváltotta a „старший матрос" (fömatróz) megnevezés.
} 
tulajdonképpen teljesen önkényesnek tekinthető, hiszen Magyarországon - sajátos történelmi és földrajzi adottságainkból adódóan - semmilyen ehhez fogható beosztás nincsen, és nem is volt soha. A „морской” jelző egyébként azért fordulhatott elő egy folyami haderőnemnél, mivel szervezetileg a Dunai Flottilla is a szovjet (Feketetengeri) haditengerészethez tartozott, ezért a flottillánál rendszeresített beosztások is ennek megfelelően alakultak.

Számtalan egyéb példát lehetne még hozni a különböző katonai szakkifejezések fordításainak nehézségeire, de talán ezek voltak a legérdekesebbek.

A teljesség kedvéért mindenképp meg kell említeni, hogy olykor még a legkörültekintőbb vizsgálat sem fog megnyugtató eredményre vezetni. A már említett földrajziés személynevekkel kapcsolatos anomáliákon túl említsünk meg röviden két köznévi példát is. Az egyik az „ажурный переплёт” elnevezésű hídelem, amely többé-kevésbé a magyar „kereszttartó” megfelelöje úgy, hogy közben az eredeti orosz kifejezés egyebek mellett speciális marófej típust is jelent. A valódi jelentés ebben az esetben csak a szövegkörnyezetből derül ki. A „санитарная машина” esetében nem az átültetés jelenti a nehézséget, hanem az, hogy az általános szóhasználat szintjén a magyar nyelv - az orosszal ellentétben - egyszerüen nem különbözteti meg a régi mentőautót az újtól. A magyaroknak a világháborús „санитарная машина” ugyanúgy mentőautó, mint a mai „машина скорой помощи”.

És a felsorolást szinte vég nélkül lehetne folytatni... Ebben a rövid elemzésben azonban igyekeztem magyar vonatkozású, illetve a katonai szaknyelv köréből vett példáknál maradni. Összegzésképpen megállapíthatom, hogy a szovjet-orosz vonatkozású magyar könyvkiadás egyik méltatlanul elhanyagolt területe a szovjet katonák magyarországi harcaival kapcsolatos visszaemlékezések kiadása. A kontraszt még nagyobb, ha mindezt összevetjük a másik fél, vagyis a német oldal anyagainak feldolgozottságával. A maga szerény eszközeivel a saját fordításom, valamint e rövid tanulmány is ezen a helyzeten kívánt változtatni.

\author{
NAgy LÁsZLó \\ kiemelt fötanár \\ Katasztrófavédelmi Oktatási Központ, Budapest \\ laccer@usa.com
}

Alexei Chkheidze, the Memoirs of a Soviet Soldier who Fought in Hungary

\begin{abstract}
There are very few published memoirs of Soviet soldiers who fought in the Second World War, despite the fact that the narratives of the ones who survived this loaded historical period may significantly shape our understanding of it. The deeds of Soviet soldiers fighting in Hungary varies greatly, from genocide to rescue, which topic is touched upon by the paper.
\end{abstract}


The article provides the translation technical analysis of the notes of the Georgian Soviet soldier, Alexei Alexandrovich Chkheidze, who fought in Hungary and met a tragic fate. It gives prominence to the fact that the literary translator often has to do the work of a technical translator: they must thoroughly research the contemporary military jargon and clothing, as well as the altered naming of various locations.

Keywords: Second World War, Soviet soldier diaries, translation principles, difficulties of translation

DOI: 10.37415/studia/2020/1-2/89-99.

Open Access: Creative Commons Attribution 4.0 International (CC BY 4.0) (c) () 